\title{
KONTRIBUSI DAN PERAN PRODUKTIF IBU DALAM MENINGKATKAN PENDAPATAN RUMAH TANGGA PETANI PADI
}

\section{Contribution And Productive Role Of Housewives In Increasing Household Income Of Rice Farmers}

\author{
Vivi Fitriyah', Ahmad Choibar Tridakusumah², \\ Program Studi Agribisnis, Departemen Sosial Ekonomi Pertanian, \\ Fakultas Pertanian, Universitas Padjadjaran, Bandung \\ *Kontak penulis: vivifitriyah01@gmail.com
}

\begin{abstract}
Economic problems faced by farmer households cause farmers to try to find ways to make their family's living fulfilled. One of the ways done by farm households is by involving family members, especially housewives, to work. This study aims to analyze the productive role of housewives in the agriculture and off-farm sectors, the amount of economic contribution made by housewives to household income. The study was conducted in Mekarjaya Village, Gantar District, Indramayu Regency, which was deliberately chosen by considering Mekarjaya Village as the center of rice production in West Java and has the largest female population. The samples in this study are 45 farmer household respondents whose wives work and obtained through the Slovin formula and taken using a simple random method. The study method used is a descriptive quantitative method. Data are analyzed with descriptive analysis and income analysis. The results show that housewives play a productive role in their lives. The productive role is carried out in various sectors, both agricultural and off-farm sectors. The contribution of housewives who perform productive roles is important, it is at $17.38 \%$. That is because their contribution can help with daily needs.
\end{abstract}

Key Words: Contribution; Productive Role; Household Income; Housewife.

\section{Abstrak}

Permasalahan ekonomi yang dihadapi oleh rumah tangga petani mengakibatkan petani berusaha untuk mencari cara agar nafkah keluarganya terpenuhi. Cara yang dilakukan oleh rumah tangga petani salah satunya yakni dengan melibatkan anggota keluarga khususnya ibu rumah tangga untuk bekerja. Penelitian ini memiliki tujuan untuk menganalisis mengenai peran produktif ibu yang dilakukan di sektor pertanian dan luar pertanian dan besarnya kontribusi ekonomi yang diberikan oleh ibu terhadap pendapatan rumah tangga. Penelitian di lakukan di Desa Mekarjaya Kecamatan Gantar Kabupaten Indramayu yang dipilih secara sengaja dengan mempertimbangkan Desa Mekarjaya sebagai sentra produksi padi di Jawa Barat dan memiliki penduduk perempuan terbesar. Sampel dalam penelitian ini sebesar 45 responden rumah tangga petani yang istrinya bekerja yang diperoleh melalui rumus slovin dan diambil dengan menggunakan metode acak sederhana. Metode penelitian yang digunakan yakni metode kuantitatif deskriptif. Data dianalisis dengan analisis deskriptif dan analisis pendapatan. Hasil penelitian menunjukan bahwa Ibu rumah tangga menjalankan peran produktif dalam kehidupannya. Peran produktif tersebut dilakukan di berbagai sektor baik itu pertanian mapun selain pertanian. Kontribusi ibu rumah tangga yang melakukan peran produktif itu penting yakni 17,38 \%. Hal tersebut disebabkan karena kontribusinya tersebut dapat membantu kebutuhan sehari- hari.

Kata Kunci : Kontribusi; Peran Produktif; Pendapatan Rumah Tangga; Ibu Rumah Tangga. 
Sitasi: Fitriyah, V., D. Tridakusumah, A.C., 2020. Kontribusi dan Peran Produktif Ibu Dalam Meningkatkan Pendapatan Rumah Tangga Petani Padi , JSEP 16(1): 1 - 10.

\section{Pendahuluan}

Pertanian merupakan salah satu sektor penting di Indonesia yang masih menjadi sumber mata pencaharian utama masyarakat pedesaan. Menurut data Badan Pusat Statistika (2018) tenaga kerja sektor pertanian yang terserap di indonesia mencapai 27. 067.835 orang. Tingginya jumlah tenaga kerja tersebut disebabkan karena sektor ini tidak memerlukan pendidikan yang tinggi serta keahlian khusus. Tenaga kerja yang terserap pada sektor pertanian di dominasi oleh tenaga kerja rumah tangga. Artinya seorang petani melibatkan beberapa anggota keluarganya untuk mengolah lahan. Kerjasama yang dilakukan di dalam rumah tangga tersebut tujuannya agar hasil usaha taninya menjadi optimal dan terdapat peran produktif dari ibu rumah tangga didalamnya.

Peran ibu dalam pemenuhan kebutuhan rumah tangga menjadi penting. Seiring berkembangnya zaman fungsi ibu rumah tangga sebagai peran produktif semakin meningkat, termasuk kontribusinya di sektor pertanian. Peran yang dilakukan produktif ibu rumah tangga tersebut bertujuan agar pendapatan rumah tangga meningkat (Widodo, 2003). Perempuan di pedesaan sebagian besar memiliki pekerjaan di sektor pertanian karena mengikuti suaminya sebagai seorang petani (Komariyah,2013). Yuwono (2013), mengatakan peran ibu rumah tangga di sektor pertanian menjadi penting mulai dari menyediakan sarana produksi pertanian hingga ke proses budidaya sampai ke pemanenan.

Keterbatasan ekonomi yang dihadapi oleh keluarga petani, mendorong ibu rumah tangga berperan dalam membantu bekerja di bidang non pertanian. Pekerjaan tersebut dilakukan di sela- sela waktu luang setelah pekerjaan utamanya selesai. Suseno (1997) mengatakan salah satu kesempatan kerja potensial non pertanian yang berada di pedesaan adalah sektor industri khususnya sektor industri. Industri kecil atau industri rumah tangga memiliki karakteristik yang hampir sama dengan sektor pertanian yakni tenaga kerja yang dibutuhkan relatif tidak memerlukan keahlian dan pendidikan yang cukup tinggi. Sektor ini adalah salah satu sektor non pertanian yang penting dalam hal penyerapan tenaga kerja khususnya di pedesaan. Untuk memperoleh tambahan pendapatan, petani khususnya ibu rumah tangga memiliki pekerjaan sampingan di sektor non pertanian. Hal tersebut didukung dengan semakin meningkatnya jumlah pekerja pada industri di Indonesia. Sektor pertanian di Jawa Barat mengalami penurunan jumlah tenaga kerja sebesar 2,33\%.) Berbeda dengan sektor pertanian, sektor industri justru setiap tahunnya mengalami peningkatan tenaga kerja. Tenaga kerja sektor industri tahun 2017 sebesar 4.185.500 dan mengalami peningkatan sebesar $7,8 \%$ dari tahun sebelumnya yang hanya sebesar 3.884.668.

Kabupaten Indramayu merupakan daerah pertanian di Jawa Barat dengan produksi padi terbesar. Dengan tanah yang subur serta luas lahan yang tinggi menjadikan Kabupaten Indramayu sebagai lumbung padi di Jawa Barat. Berdasarkan data BPS tahun 2018 Kabupaten Indramayu menempati urutan pertama 
daerah dengan produksi padi terbesar di Jawa Barat dengan total produksi sebesar 1.391.928 ton. Kabupaten Indramayu terbagi menjadi 31 Kecamatan, dari 31 kecamatan tersebut semuanya terdapat lahan sawah dan memproduksi padi dalam jumlah yang bervariasi setiap kecamatannya. Kecamatan Gantar merupakan kecamatan yang memiliki produksi padi terbesar di Kabupaten Indramayu yakni dengan total produksi sebesar 108.328,65 ton (BPS, 2017). Meskipun demikian masih banyak petani yang hidupnya kurang sejahtera. Hal tersebut dapat terlihat dari masih tingginya angka penerima raskin dan jumlah keluarga pra sejahtera. Sebagai kabupaten yang menghasilkan produksi padi terbesar di Jawa Barat seharusnya masyarakat Kabupaten Indramayu tidak mengalami kesulitan dalam memperoleh beras. Pada kenyatannya justru sebaliknya masyarakat Kabupaten Indramayu memperoleh bantuan raskin/ rastra/ BNPT dalam jumlah yang tinggi yakni sebesar 60,32\% (BPS, 2018). Selain itu, keluarga pra sejahtera atau keluarga miskin di Indramayu juga jumlahnya cukup tinggi yakni sebesar 176.495 keluarga (BPS, 2015).

Kecamatan Gantar merupakan sentra produksi padi di Kabupaten Indramayu, dan memiliki jumlah penduduk perempuan yang besar $(49,21 \%)$ (BPS, 2017). Desa Mekarjaya adalah desa di Kecamatan Gantar yang merupakan sentra utama padi. Jumlah penduduk perempuan di desa Mekarjaya ini juga merupakan yang tertinggi di Kecamatan Gantar yakni sebesar 9.668 (BPS, 2016). Selain itu, Desa Mekarjaya merupakan desa dengan jumlah keluarga pra sejahtera tertinggi di Kecamatan Gantar. Hal tersebut memperlihatkan bahwa satu sisi Desa Mekarjaya menjadi sentra produksi padi di Kecamatan Gantar, sisi lain keluarga petaninya tidak sejahtera.

Keadaan keluarga yang tidak sejahtera tersebut mendorong ibu untuk membantu suaminya bekerja dan mencari nafkah baik itu di sektor pertanian maupun disektor selain pertanian. Keterlibatan dalam sektor pertanian dilakukan dengan membantu kegiatan usaha tani, tetapi keterlibatannya tersebut tidak memberikan peningkatan pendapatan keluarga. Oleh sebab itu, ibu rumah tangga juga membanu suami dengan memiliki pekerjaan di luar sektor pertanian. Berdasarkan hal tersebut peran yang dilakukan oleh perempuan memberikan peningkatan pendapatan keluarga.

Jumlah atau proporsi penduduk perempuan yang besar di Desa Mekarjaya, tentunya peran produktif dari ibu rumah tangga tersebut diharapkan bisa membantu meningkatkan pendapatan yang diterima oleh keluarga. Oleh karena itu, peneliti memiliki ketertarikan untuk melakukan penelitian mengenai kontribusi dan peran produktif yang dilakukan oleh ibu dalam meningkatkan pendapatan rumah tangga petani padi.

\section{Metode Penelitian}

Penelitian dilaksanakan di Desa Mekarjaya, Kecamatan Gantar, Kabupaten Indramayu. Lokasi penelitian dipilih secara purposive dengan mempertimbangkan bahwa Desa Mekarjaya Kecamatan Gantar adalah desa yang menghasilkan produksi padi serta memiliki jumlah penduduk perempuan terbesar di Kabupaten Indramayu. Objek dalam penelitian ini yakni kontribusi ekonomi ibu rumah tangga dan peran produktif petani yang kaitannya dengan pendapatan. Sedangkan subjek dalam penelitian ini adalah ibu rumah tangga yang memiliki suami dan membantu suaminya bekerja diberbagai sektor. Penelitian ini menggunakan desain penelitian kuantitatif deskriptif. Pengambilan sampel dalam penelitian ini dilakukan dengan 
menggunakan teknik simple random sampling. Penentuan jumlah sampel dilakukan dengan rumus slovin dan diperoleh responden sebanyak 45 ibu rumah tangga. Data dalam penelitian ini dianalisis secara deskriptif dan menggunakan metode analisis lainnya. Berikut merupakan metode analisis lainnya:

\section{Analisis Usahatani Padi}

Analisis usahatani padi bertujuan untuk menghitung seluruh biaya dan keuntungan yang diterima petani dalam melakukan usahatani padi. Analisis usahatani padi ini didalamnya mencakup perhitungan biaya total dan hasil penjualan atau penerimaan. Pendapatan usahatani dilakukan dengan menghitung selisih antara penerimaan dengan biaya total yang dikeluarkan dalam satu kali musim tanam.

$$
\begin{aligned}
& \pi \quad=\mathrm{TR}-\mathrm{TC} \\
& \text { Keterangan: } \\
& \pi \quad=\text { Pendapatan } \\
& \mathrm{TR} \quad=\text { total revenue (Total Penerimaan) } \\
& \mathrm{TC} \quad=\text { total cost (biaya total) }
\end{aligned}
$$

\section{Analisis Pendapatan Rumah Tangga}

Rumah tangga petani padi memiliki berbagai pekerjaan dalam kesehariannya. Oleh sebab itu, perhitungan pendapatan dihitung dari seluruh pekerjaan yang dilakukan oleh petani baik itu dari pekerjaan utama ataupun sampingan. Pekerjaan utama yakni dengan menjadi petani dan pekerjaan sampingan yakni pada kegiatan off farm dan selain pertanian. Besarnya pendapatan rumah tangga diperoleh dari dari suami, istri, serta kontribusi dari anak. Perhitungan total pendapatan rumah tangga sebagai berikut:

a. Pendapatan dari berbagai sektor

$$
\mathrm{P}=\mathrm{P}_{\text {onfarm }}+\mathrm{P}_{\text {offfarm }}+\mathrm{P}_{\text {nonfarm }}
$$

$$
\begin{aligned}
& \text { Keterangan: } \\
& \mathrm{P}_{\text {usahatanipadi }}=\text { Pendapatan usahatani/ tahun } \\
& \mathrm{P}_{\text {off farm }}=\text { Pendapatan buruh tani/ agroindustri/ tahun } \\
& \mathrm{P}_{\text {nonpertanian }}=\text { Pendapatan selain pertanian } / \text { tahun }
\end{aligned}
$$

b. Pendapatan total Rumah Tangga

$\mathrm{TPRT}=\mathrm{PS}+\mathrm{PI}+\mathrm{PL}$

Keterangan:

TPRT $=$ Pendapatan rumah tangga

PS = Pendapatan suami

PI $=$ Pendapatan istri

$\mathrm{PL}=$ Pendapatan sumber lain 


\section{Analisis Kontribusi}

Kontribusi ibu terhadap pendapatan rumah tangga dianalisis dengan menghitung pendapatan yang diperoleh dari berbagai sektor, kemudian pendapatan tersebut dibandingkan dengan total pendapatan rumah tangga. Selain itu, dalam kontribusi ini juga dihitung curahan waktu yang diberikan oleh ibu rumah tangga yang melakukan pekerjaan pada kegiatan on farm. Berikut merupakan rumus yang digunakan dalam perhitungan kontribusi:

$$
\text { Kontribusi }(\%)=\frac{\text { Pendapatan yang diterima Ibu }}{\text { Pendapatan Total Rumah Tangga }} \times 100
$$

\section{Hasil dan Pembahasan}

Penelitian ini memiliki 45 orang responden ibu rumah tangga yang memiliki suami dan membantu suaminya bekerja di berbagai sektor. Hasil penelitian menunjukan rata- rata ibu rumah tangga memiliki usia produktif yakni 48 tahun. Tingkat pendidikan ibu rumah tangga masih tergolong rendah. Sebesar $51,1 \%$ ibu rumah tangga tidak pernah menempuh pendidikan. Pendidikan tertinggi yang ditempuh yakni hanya SMP sebesar 13,3\%. Sebagian besar rumah tangga petani dalam penelitian ini memiliki jumlah tanggungan yang kecil yakni kurang dari 4 orang dengan persentase sebesar $87 \%$. Rata- rata pengalaman usahatani ibu rumah tangga ini cukup lama yakni diatas 20 tahun. Artinya ibu rumah tangga dalam penelitian ini sudah berpengalaman dalam usahatani padi.

\section{Peran Produktif Ibu Rumah Tangga}

Perempuan dalam kesehariannya memiliki berbagai peran, bukan hanya memiliki peran ganda tetapi memiliki triple role, yakni peran domestik, sosial komunitas, dan peran produktif (Mosser, 1999). Dalam menjalankan kehidupannya perempuan menjalankan tiga peran tersebut khususnya ibu atau istri petani di pedesaan. Ibu rumah tangga menjalankan berbagai peran tersebut dalam kesehariannya. Peran domestik adalah peran yang dijalankan oleh ibu rumah tangga di dalam rumah seperti seperti memasak, mencuci piring, mengurus anggota rumah tangga dan yang lainnya. Ibu rumah tangga juga menjalankan peran sosial komunitas agar terciptanya hubungan yang baik antara anggota rumah tangga di dalam masyarakat. selain itu, ibu rumah tangga juga menjalankan peran produktif yakni dengan bekerja dan mencari nafkah. Hasil penelitian dari Puspitawati dan Fahmi (2008) diperoleh bahwa ibu rumah tangga dominan dalam kegiatan domestik seperti mengurus anak dan yang lainnya, kegiatan yang berhubungan dengan kegiatan ekonomi dominan dilakukan oleh suami, tetapi dalam hal ini ibu rumah tangga juga terlibat walaupun keterlibatannya masih kecil, untuk kegiatan yang berhubungan dalam usahatani, kegiatan tersebut dilakukan secara bersama.

Seluruh ibu rumah tangga dalam penelitian ini terlibat dalam aktivitas usaha tani padi sawah. Motivasi keterlibatannya tersebut adalah guna membantu suami di sawah dan mengikuti pekerjaan suami. Selain itu, keterlibatannya tersebut bertujuan untuk mengisi waktu luang. Hasil penelitian Darayani et al., (2015) yang menyatakan bahwa motivasi dari ibu rumah tangga untuk bekerja yakni untuk 
mengisi waktu luang (84,1\%), tidak memiliki keterampilan lain $(67,68 \%)$, dan memenuhi kebutuhan ekonomi sebesar (60,94\%).

Keterlibatan ibu rumah tangga tidak hanya pada kegiatan on farm yakni dengan membantu suami di sawah, namun ibu rumah tangga juga terlibat dalam kegiatan off farm dan non farm. Keterlibatan ibu rumah tangga dalam usahatani dilakukan dari proses awal budidaya hingga pada saat pemanenan. Sebagian besar ibu rumah tangga terlibat dalam segala aktivitas usahatani mulai dari penanaman, pemberian pestisida, penyiangan, pemupukan, dan pemanenan. Keterlibatan ibu rumah tangga yang paling dominan adalah pada saat penanaman. Hal tersebut disebabkan untuk proses pengolahan lahan seluruhnya dikerjakan oleh laki-laki, karena pengolahan lahan merupakan pekerjaan yang cukup berat.

Seiring berkembangnya zaman dan tuntutan kebutuhan sehari- hari yang terus meningkat ibu rumah tangga tidak hanya melakukan peran produktif pada sektor pertanian saja melainkan dilakukan pada sektor selain pertanian. Keterlibatan ibu rumah tangga dalam peran produktif di sektor lain masih kecil, sehingga kontribusi yanng diberikannya pun masih rendah. Hal tersebut disebabkan karena pekerjaan diluar sektor pertanian yang dapat dijangkau ibu rumah tangga tidak banyak dan sebagian besar dilakukan hanya di Desa Mekarjaya. Penyebabnya lapangan pekerjaan untuk ibu rumah tangga di Desa Mekarjaya ini tidak terbuka luas dan ibu rumah tangga juga tidak memiliki keahlian khusus serta memiliki pendidikan yang rendah. Keterlibatan ibu rumah tangga dalam berbagai kegiatan produktif dapat dilihat pada Gambar 1.

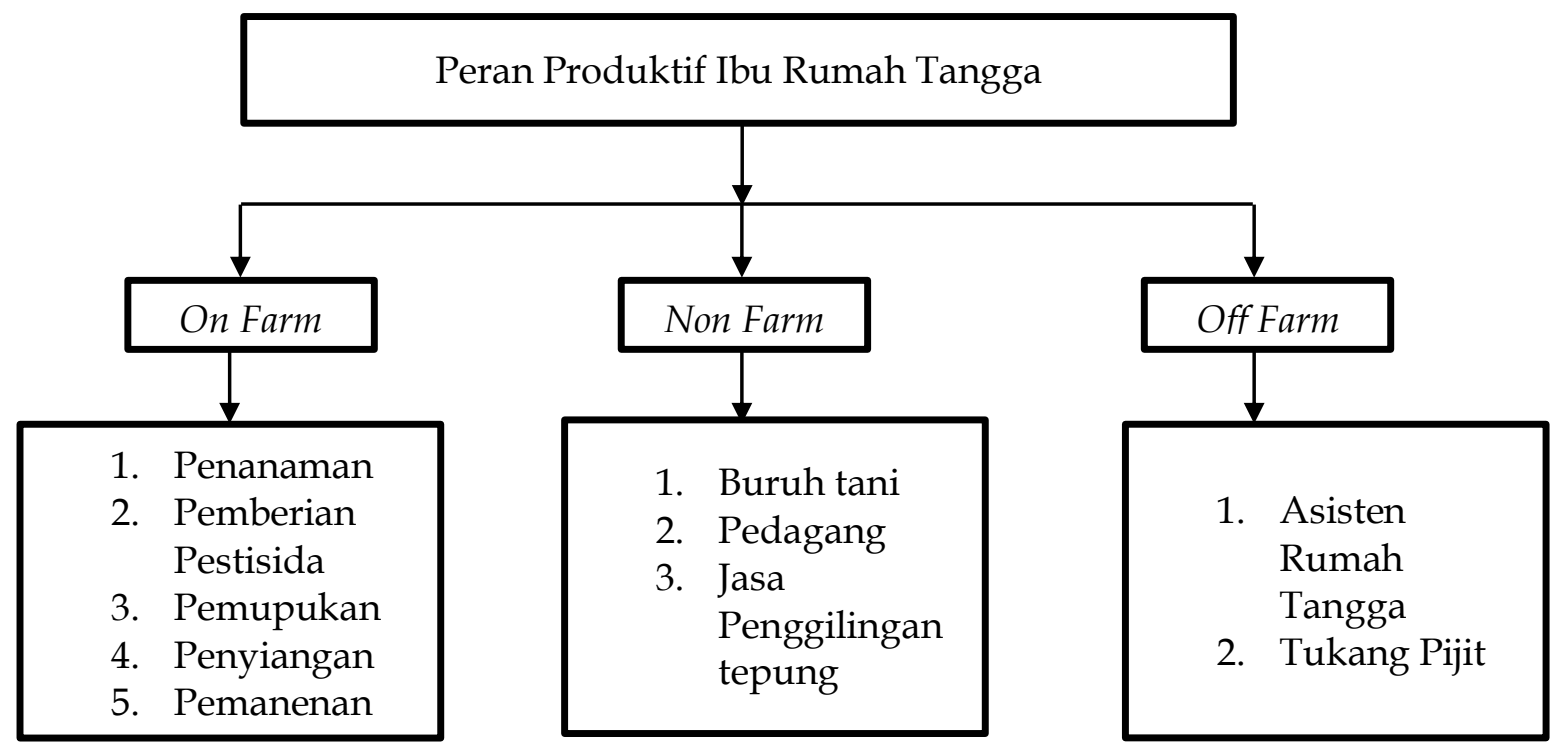

Gambar 1 Skema Peran Produktif Ibu Rumah Tangga

Pekerjaan selain pertanian yang dilakukan oleh ibu rumah tangga yakni dengan menjadi asisten rumah tangga (infal), dan tukang pijit. Pekerjaan menjadi asisten rumah tangga atau infal di Jakarta hanya dilakukan sekali yakni pada saat mendekati hari lebaran idul fitri dan beberapa hari setelahnya. Upah dalam melakukan pekerjaan tersebut yakni sebesar Rp 200.000/ hari. Untuk pekerjaan menjadi tukang pijit dilakukan apabila ada yang membutuhkan, sehingga pekerjaan tersebut waktunya tidak menentu. Upah untuk pekerjaan tersebut yakni Rp 50.000. 
Kegiatan off farm yang dilakukan oleh ibu rumah tangga yakni dengan menjadi buruh tani, berdagang, dan yang lainnya. Pekerjaan menjadi pedagang dilakukan sepanjang tahun. Beberapa ibu rumah tangga memiliki warung yang menjual jajanan- jajanan ringan serta kebutuhan sehari- hari lainnya. Selain itu, terdapat ibu rumah tangga yang berjualan makanan yakni berupa makanan lauk pauk, nasi uduk, dan bakpau. Ibu rumah tangga yang berjualan makanan dilakukan di pagi hari mulai dari pukul 06:30 hingga 08:00. Sedangkan untuk yang berjualan bakpau dilakukan dengan menitipkan bakpau tersebut ke warung- warung disekitar desa.

Ibu rumah tangga di Desa Mekarjaya juga memiliki pekerjaan sebagai buruh tani. Pekerjaan menjadi buruh tani tersebut dilakukan disela- sela waktu mengurus lahan milik sendiri. Upah yang diterima selama menjadi buruh tani yakni Rp 50.000 hingga Rp 60.000. Upah tersebut diberikan untuk waktu kerja setengah hari yakni dari pukul 07:00- 12:00. Upah yang diterima buruh tani perempuan ini jumlahnya lebih kecil dibandingkan dengan upah buruh tani laki- laki.

Keterlibatan ibu rumah tangga dalam sektor pertanian dapat dikatakan cukup tinggi sedangkan keterlibatannya dalam sektor non pertanian masih rendah. Penyebabnya adalah selain karena lapangan pekerjaan di desa yang tidak ada, ibu rumah tangga juga harus tetap menjalankan peran domestiknya di dalam rumah tangga karena mobilitas suami di Desa Mekarjaya untuk bekerja di kota cukup tinggi.

\section{Pendapatan Usahatani Padi}

Soekartawi (1984), mendefinisikan pendapatan usahatani sebagai selisih antara penerimaan dengan total biaya yang dikeluarkan dalam melakukan usahatani. Pendapatan untuk usahatani padi diperoleh dua kali musim selama satu tahun. Petani dalam penelitian ini merupakan petani tadah hujan yang artinya penanaman padi akan dilakukan apabila memasuki musim hujan. Luas lahan ratarata yang dikerjakan oleh petani yakni sebesar $0,7 \mathrm{Ha}$ atau 1 bahu. Rata- rata pendapatan dalam satu tahun yang diperoleh dalam usahatani padi ini sebesar Rp 22.112.154. Dalam melakukan usahatani padi ibu rumah tangga juga terlibat dalam berbagai kegiatan usahatani mulai dari penanaman sampai ke pemanenan. Oleh sebab itu besarnya rata- rata pendapatan yang diperoleh ibu sebesar Rp 4.427.318 dari total pendapatan. Pendapatan tersebut diperoleh dengan menghitung curahan waktu kerja yang dilakukan oleh ibu rumah tangga dalam usahatani padi.

\section{Pendapatan Peternakan}

Pendapatan peternakan ini merupakan pendapatan yang diperoleh dari memelihara hewan ternak. Petani selain mengusahakan komoditas padi juga memiliki dan memelihara hewan ternak. Petani hanya memiliki hewan ternak berupa kambing. Kambing tersebut jumlahnya bervariasi. Dalam satu tahun petani dapat menjual kambing yang dipeliharanya berkisar antara 2-4 kambing. Besarnya rata- rata pendapatan dalam satu tahun dari peternakan ini sebesar Rp 1.022.222. 


\section{Pendapatan Off Farm}

Petani memiliki berbagai pekerjaan dalam kesehariannya. Selain mengusahakan komoditas padi dan memelihara hewan ternak, petani juga memiliki pekerjaan di sektor off farm. Pendapatan off farm diperoleh dari upah menjadi buruh tani atau diperoleh dari mengusahakan kegiatan agroindustri atau yang lainnya. Petani (suami) yang memiliki pendapatan off farm dalam penelitian ini sebesar 22,22 \%. Rata- rata pendapatan suami dalam kegiatan off farm ini sebesar Rp 606.666. Besarnya rata- rata pendapatan off farm ibu rumah tangga dalam 1 tahun yakni Rp 197.777.

\section{Pendapatan Non Pertanian}

Pendapatan non pertanian merupakan pendapatan yang diperoleh dari kegiatan selain pertanian atau tidak berhubungan dengan pertanian. Petani yang pendapatannya rendah dan merasa kekurangan, akan berusaha untuk mencari pekerjaan lain diluar sektor pertanian. Pekerjaan di luar sektor pertanian tersebut dilakukan oleh suami ataupun ibu rumah tangga. Waktu dalam melakukan pekerjaan ini bervariasi yakni dilakukan sepanjang tahun atau dilakukan setelah musim tanam selesai. Pekerjaan yang dilakukan oleh suami diluar sektor pertanian ini antara lain dengan menjadi buruh pabrik, supir, buruh bangunan dan yang lainnya. Rata- rata pendapatan yang diperoleh suami dalam pekerjaan diluar pertanian ini sebesar Rp 1.403.333. Besarnya rata- rata pendapatan ibu rumah tangga pada kegiatan non pertanian ini yakni Rp 86.666.

\section{Kontribusi Ibu Rumah Tangga}

Keterbatasan ekonomi yang dirasakan oleh rumah tangga petani menjadikan ibu rumah tangga untuk ikut bekerja dan memiliki kontribusi terhadap pendapatan rumah tangga. Dalam kegiatan usahatani padi ibu rumah tangga memberikan kontribusi berupa waktu dan tenaga untuk membantu suami dalam proses budidaya padi. Selain itu, ibu rumah tangga juga berkontribusi terhadap pendapatan keluarga yang diperoleh dari pekerjaan menjadi buruh tani atau pekerjaan off farm lainnya dan pekerjaan selain pertanian. Total pendapatan dan kontribusi ibu rumah tangga dapat dilihat pada Tabel 1:

Berdasarkan Tabel 1 dapat diketahui bahwa pendapatan rumah tangga petani diperoleh dari berbagai sumber. Pendapatan tersebut juga diperoleh dari suami, istri, dan pemberian anak. Berdasarkan tabel tersebut dapat diketahui jug bahwa pendapatan yang diperoleh suami ini mendominasi pendapatan yang diperoleh rumah tangga. Sedangkan, ibu rumah tangga hanya memberikan kontribusi sebesar 17,38\%. Samadi (2001) tenaga kerja memberikan kontribuisi terhadap pendapatan keluarga dan bisa dihitung dengan persentase. Apabila kontribusi $<50 \%$ maka kontribusinya kecil, lebih dari 50\% kontribusi nya besar dan $=50 \%$ kontribusi nya sedang. Kontribusi ibu rumah tangga dalam penelitian ini termasuk kecil karena masih kurang dari 50\%. Upah yang diterima atau pendapatan yang diterima oleh ibu rumah tangga ini lebih kecil dari pendapatan suami. Hal tersebut yang menyebabkan kontribusi dari ibu rumah tangga ini masih rendah. Hasil penelitian Puspitasari (2013) di Cianjur Jawa Barat menunjukan bahwa kontribusi ibu rumah 
tangga terhadap pendapatan keluarga yakni sebesar 11,3\%. Kontribusi pendapatan nya tersebut diperoleh dari mengusahakan tanaman bunga potong yang berada di depan pekarangan rumah.

Tabel 1

Total Pendapatan Rumah Tangga dan Kontribusi Ibu Rumah Tangga terhadap Pendapatan

\begin{tabular}{|c|c|c|c|}
\hline No & Uraian Pendapatan & Pendapatan (Rp/ Tahun) & Kontribusi (\%) \\
\hline \multirow[t]{6}{*}{1.} & Suami & & 82,46 \\
\hline & Usahatani padi & 17. 684.836 & \\
\hline & Peternakan & 1.022 .222 & \\
\hline & Off farm & 606.666 & \\
\hline & Selain Pertanian & 1.403 .333 & \\
\hline & Total & 21.001 .500 & \\
\hline \multirow[t]{5}{*}{2.} & Istri & & 17,38 \\
\hline & Usahatani Padi & 4.142 .875 & \\
\hline & Off farm & 197.777 & \\
\hline & Selain Pertanian & 86.666 & \\
\hline & Total & 4.427 .318 & \\
\hline 3. & Kontribusi Anak & 38.333 & 0,15 \\
\hline \multicolumn{2}{|c|}{$\begin{array}{l}\text { Total Rata- rata Pendapatan/ } \\
\text { Tahun }\end{array}$} & 25.467 .151 & \\
\hline \multicolumn{2}{|c|}{$\begin{array}{l}\text { Total Rata- rata Pendapatan/ } \\
\text { Bulan }\end{array}$} & 2.122 .262 & \\
\hline
\end{tabular}

\section{Kesimpulan}

Ibu rumah tangga menjalankan peran produktif dalam kehidupannya. Peran produktif tersebut tidak hanya membantu suami di sawah dalam menggarap padi, tetapi ibu rumah tangga juga membantu mencari nafkah dengan berkerja sebagai buruh tani dan memiliki pekerjaan lainnya diluar sektor pertanian. Peran produktif dan kontribusi ekonomi yang dilakukan oleh ibu rumah tangga tersebut dapat dikatakan cukup penting yakni sebesar 17,38 \%. Hal tersebut disebabkan apabila ibu rumah tangga tidak membantu suaminya untuk bekerja maka pendapatan petani akan semakin rendah, dan kebutuhan tidak tercukupi.

\section{Daftar Pustaka}

BPS. (2017). Kabupaten Indramayu Dalam Angka 2017.

BPS. (2017). Kecamatan Gantar Dalam Angka 2018.

Darayani, N., Sobri, K., \& Kurniawan, R. (2015). Motivasi Tenaga Kerja Wanita 
Dalam Meningkatkan Pendapatan Keluarga Melalui Usahatani Nenas (Ananas Comusus L. Merr) Di Desa Lubuk Karet Kecamatan Betung Kabupaten Banyuasin), 62-66.

Komariyah. (2003). Profil Wanita Buruh Tani dalam Usaha Meningkatkan Kesehatan Desa Wonorejo Kecamatan Srengat Kabupaten Blitar. ITB. Bandung

Mosser. 1999. Gender Planning in the Third World: Meeting Practical and Strategic Gender Needs, World Development.

Puspitawati H, S. A. F. (2008). Analisis Pembagian Peran Gender Pada Keluarga Petani, 1-10.

Puspitasari, N. (2012). Peran Gender, Kontribusi Ekonomi Perempuan dan Kesejahteraan Keluarga Petani Hortikultura (Kasus di Dusun Padajaya, Desa Sindangjaya, Kecamatan Cipanas, Kabupaten Cianjur).

Samadi, Budi. 2001. Kinerja Tenaga Kerja Wanita. Yogyakarta: Graha Ilmu.

Suseno, P. (1997). Pengaruh Faktor Sosial Ekonomi terhadap Pekerjaan Sampingan Masyarakat Pedesaan.

Soekartawi. 1984. Ilmu Usahatani dan Penelitian untuk Pengembangan Petani Kecil. Jakarta: Universitas Indonesia

Widodo. 2003. Analisis Faktor- Faktor yang Mempengaruhi Ibu Rumah Tangga Bekerja Di Sektor Non Pertanian dalam Meningkatkan Pendapatan Keluarga. Program Pasca Sarjana Universitas Brawijaya.

Yuwono, D. M. (2013). Pengarusutamaan gender dalam pembangunan pertanian: kasus pada pelaksanaan program, 10(1), 140-147 